\title{
Mating moths (Tineidae, Ditrysia, Lepidoptera) preserved as frozen behavior inclusion in Baltic Amber (Eocene)
}

\author{
Thilo C. Fischer and Marie K. Hörnig
}

\begin{abstract}
The investigation of amber inclusions provides a unique insight into the biology of animals living millions of years ago, due to their exceptional preservation in nearly lifelike conditions. This is not only true for morphological aspects, aspects of behavior can also be deduced from these fossils.

Here, Microlepidoptera are reported from Eocene Baltic amber most likely as a first occurrence of fossil Lepidoptera found in copula. The moths belong to Tineidae (tineid moths includes clothes moths) and are described as a new species and new genus, Forcepsites michalskii. The clasping organ of the male is quite uncommon for moths from Baltic amber, with a ventral and dorsal part, each ending in two parallel, thorn-like protuberances, and seemingly not being formed by the valvae. The co-occurrence of male and female, most likely in copula, allowed studying their sexual dimorphism directly, and there is evidence that the habitat of this species is the site of resin production in the Baltic amber forest. From sexual dimorphism of the antennae and eye morphology it is interpreted that the female was the calling sex for mating in this species.
\end{abstract}

Thilo C. Fischer. Förderverein der Bayerischen Staatssammlung für Paläontologie und Historische Geologie München Richard-Wagner-Straße 10, D-80333 München, Germany. thilo.fischer@tum.de Marie K. Hörnig. University of Greifswald, Zoological Institute and Museum, Cytology and Evolutionary Biology, Soldmannstr. 23, D-17489 Greifswald, Germany. marie.hoernig@palaeo-evo-devo.info

KEYWORDS: Clothes moths; habitat in copula; Microlepidoptera; new species and genus; sexual dimorphism

Submission: 22 October 2017 Acceptance: 23 January 2019

http://zoobank.org/BCF64D89-6879-4805-8021-7CE926CE4B12

Fischer, Thilo C, and Hörnig, Marie K. 2019. Mating moths (Tineidae, Ditrysia, Lepidoptera) preserved as frozen behavior inclusion in Baltic Amber (Eocene). Palaeontologia Electronica 22.1.7A 1-11. https://doi.org/10.26879/829

palaeo-electronica.org/content/2019/2421-mating-moths

This is an open access article distributed under the terms of Attribution-NonCommercial-ShareAlike 4.0 International (CC BY-NC-SA 4.0), which permits users to copy and redistribute the material in any medium or format, provided it is not used for commercial purposes and the original author and source are credited, with indications if any changes are made.

creativecommons.org/licenses/by-nc-sa/4.0/ 


\section{INTRODUCTION}

Mating insects are rarely found in amber as cases of the so-called 'frozen behavior' (Arillo, 2007, and references therein). Such have been reported from Eocene Baltic amber, for example from the groups Diptera, Coleoptera, Hemiptera, Hymenoptera and quite rarely Trichoptera (Weitschat and Wichard, 2002; Weitschat, 2009; Boucot and Poinar Jr., 2010; Gröhn, 2016).

In Baltic amber, Lepidoptera are generally rare and occur at about one in 250 inclusions (for comparison: Dipterans represent about $64 \%$ of all insects in Baltic amber, Lepidoptera represent about 0.4 \%; Hoffeins and Hoffeins 2003; Gröhn 2016). As in other insects, imagos preserved in copula are much rarer and Lepidoptera in copula have not yet been described, not even in other ambers or from non-amber insect localities (Sohn et al., 2012; Sohn and Lamas, 2013). An in copula occurrence allows bona fide affiliation of both sexual forms to each another and both together to a distinct species, and hence the exact description of sexual dimorphism of a species. Alternatively, sexual dimorphism from fossil insects can only be studied by statistical means whenever findings of a species are abundant as in many Nematocera (e.g., Borkent, 1995).

Tineidae are highly divergent basal representatives of the lepidopteran group Ditrysia (Regier et al., 2014), their larvae feed on a wide range of substrates (detritus, fungi, lichens, or keratin) (Scoble, 1995), hence being generalist (85.7\%) (Menken et al., 2009). As Baltic amber inclusions, Tineidae represent about a quarter of all lepidopteran findings (Skalski, 1977). Here, a rare and new species of Tineidae is described with its sexual forms from a putative in copula occurrence.

\section{MATERIALS AND METHODS}

The amber specimen was found by and purchased from Artur Michalski (Wroclaw, Poland). It was preserved by treatment with an acryl varnish and is from the author's (TF) collection with the collection number 7131 . Storage occurred at constant temperature in plastic clip bags within metal boxes, excluding oxygen and light. It will be deposited at the Bayerische Paläontologische Staatssammlung München with the number SNSB-BSPG 2017 I 113.

The specimen was photographed with a Canon EOS 70d equipped with a Canon MP-E $65 \mathrm{~mm}$ objective and a Canon Twin Flash MT-24. To avoid reflections, polarization filters were mounted and adjusted in front of the flashes and the camera objective (cross-polarized light). To reduce convexity and concavities of the amber surface, a drop of glycerin was applied and covered with a cover slip. The recorded image z-stacks were fused with Combine ZP and further processed with Adobe Photoshop CS 3. The inclusion could not be studied by micro-computer-tomography, because of the presence of metallic, seemingly pyritic inclusions, which cause strong artifacts.

\section{SYSTEMATIC PALAEONTOLOGY}

\author{
Systematics (according to van Nieukerken et al., \\ 2011) \\ Order LEPIDOPTERA Linnaeus, 1758 \\ Clade DITRYSIA Börner, 1925 \\ Superfamily TINEOIDEA Latreille, 1810 \\ Family TINEIDAE Latreille, 1810 \\ Genus Forcepsites nov. gen. \\ zoobank.org/DDB6884D-845A-4A87-981E-A2953ADD8964
}

Etymology. "Forceps", latin for forceps, referring to the male clasping organ.

Species Forcepsites michalskii nov. spec.

zoobank.org/5494D58E-7773-473C-AFB2-140DDD049226

Holotypus. Specimen ex coll. Fischer no. 7131, Figure 1.2

Locus typicus. Amber mine of Yantarni, GUS

Stratum typicum. "Blaue Erde" (upper Eocene lower Oligocene)

Etymology. The species name michalskii is chosen to acknowledge Artur Michalski for providing this specimen.

Repository. Bayerische Staatssammlung für Paläontologie und Geologie, Munich, Germany; accession number SNSB-BSPG 2017 I 113.

Diagnosis of genus. Monotypic genus with the clasping organ of the male (Figure 2.3) with a ventral and dorsal part, each ending in two parallel, thorn-like protuberances, as the defining character. Diagnosis of species. The respective qualitative and quantitative characters of the female and male imagos (Figure 1) were determined and are summarized in Table 1.

Differential diagnosis. The combination of characters small proboscis with separated galeae, long and folded maxillary palps with five segments, upwards pointing and slightly bent labial palps with lateral bristles, head with many erect hair-like scales strongly suggest an affiliation to Tineidae, but none of these is apomorphic, neither is such an apomorphy currently known for adult Tineidae (Regier et al., 2014). The veins R4 and R5 are not 

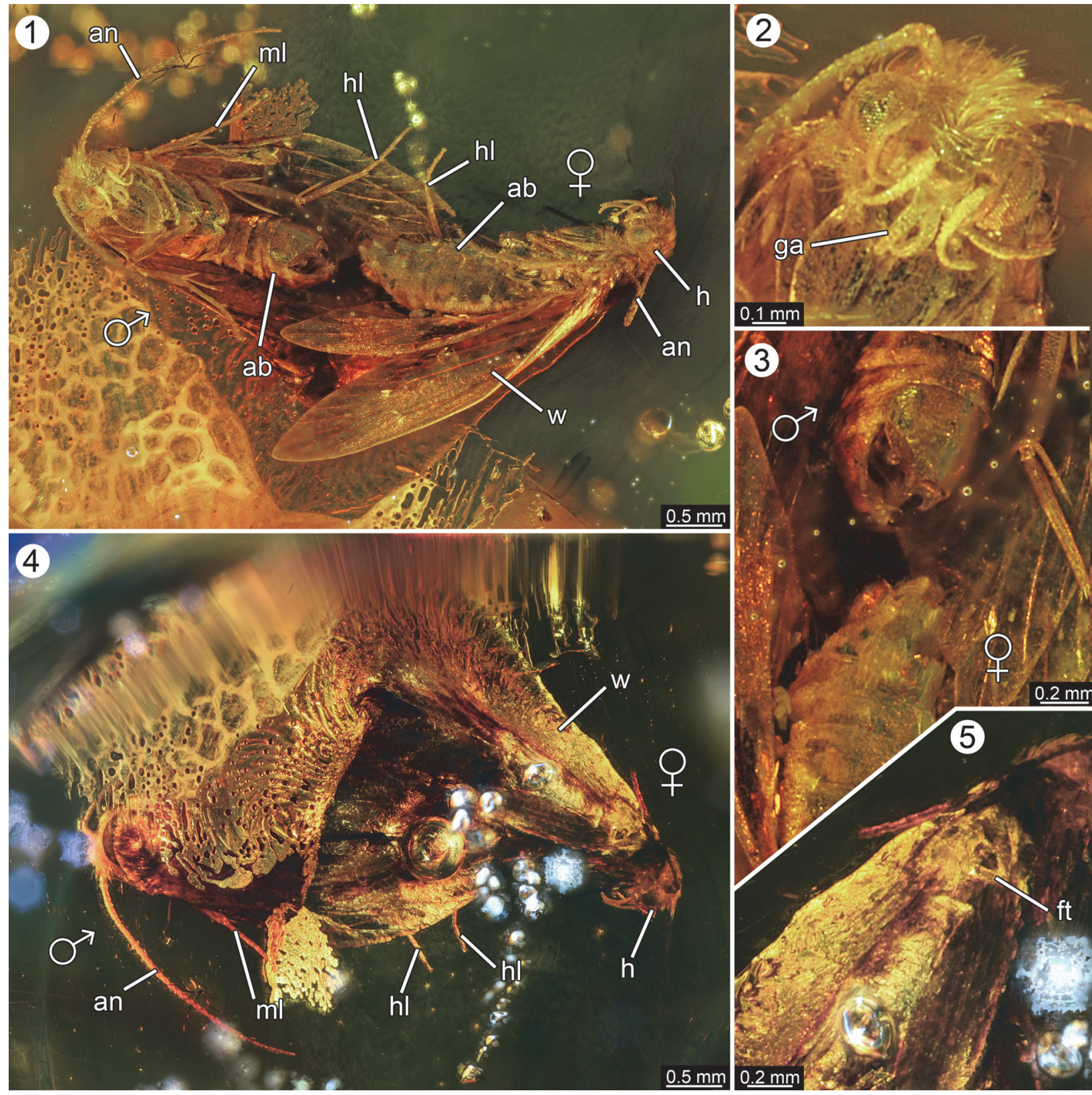

FIGURE 1. Moths in Baltic amber (specimen SNSB-BSPG 2017 I 113). 1: Overview image in ventral view of male and latero-ventral view of female. 2: Close-up image of 1, head of male. 3: Close-up image of 1, showing abdomina of male and female. 4: Overview image in dorsal view of male (partly covered by other inclusions) and dorso-lateral view of female. 5: Close-up image of 4, parts of wings and thorax of the female. Abbreviations: ab - abdomen, an antenna, $\mathrm{ft}$ - feeding traces, ga - galea, $\mathrm{h}$ - head, $\mathrm{hl}$ - hind leg, $\mathrm{ml}$ - middle leg, $\mathrm{w}$ - wing.

fused / stalked, which would be indicative for Gelechioidea (Gelechiidae and Oecophoridae) (Scoble, 1995), the other major group of Lepidoptera found in Baltic amber. The species is unlike any described representative of Tineidae or other families from Baltic amber (Rebel, 1934, 1935; Kuznezov, 1941; Skalski, 1973; Kozlov, 1987, 1988; Sohn et al., 2012; Sohn and Lamas, 2013), especially with respect to its male genital apparatus. Most similar seems Tineosemopsis decurtatus Skalski 1974 (female known) but differs in the absence of erect hairs at the vertex and its smaller eyes. Tillyardinea eocaenica Kusnezov 1941 (female), which has erect scales at the vertex and a similar venation, differs in its frons and labial palps. Simulotinea intermedia Skalski 1977 has a 


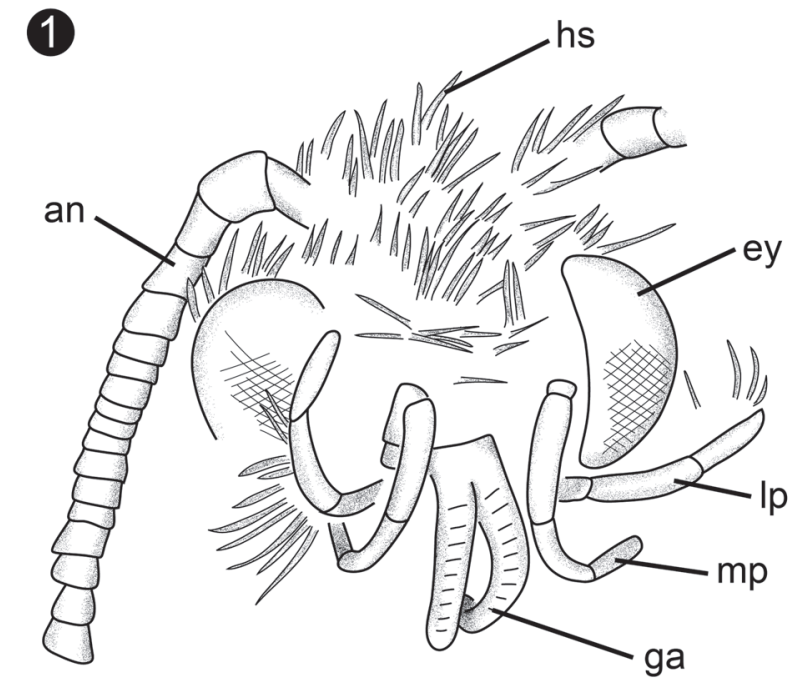

3

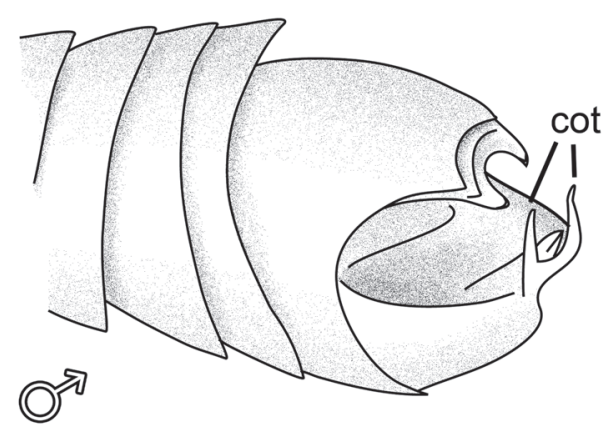

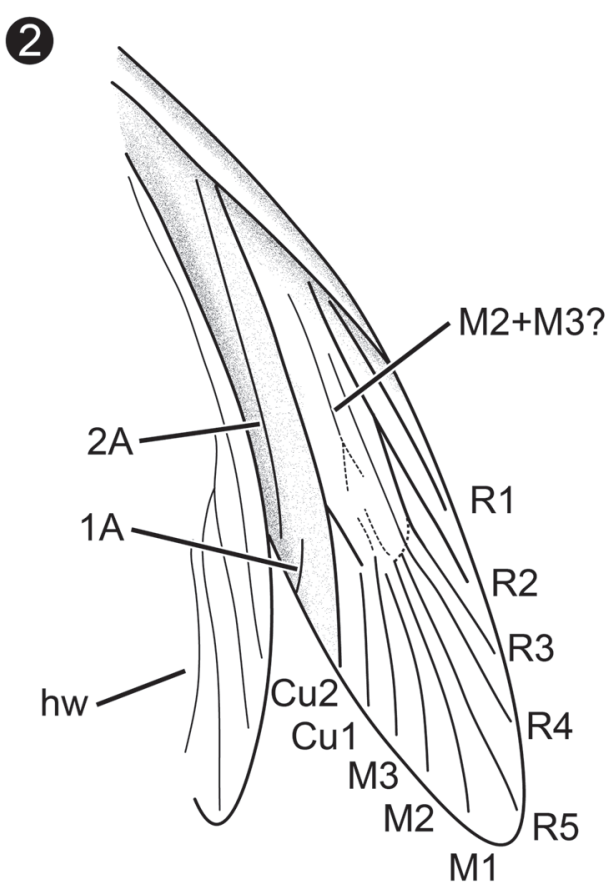

(†)

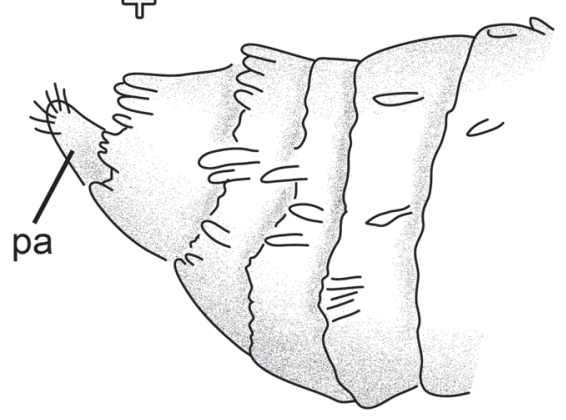

FIGURE 2. Drawings of character relevant for systematic affiliation: 1: head of male. 2: fore wing venation of female. 3: genitalia of male with clasping organ (left) and female (right). Abbreviations: an - antenna, cot - clasping organ thorns, ey - compound eye, ga - galea, hs - erect hair-like scales, hw - hindwing, mp - maxillary palps, Ip - labial palps, pa - papillae anales.

habitus alike but also differs in the presence of a bifurcated vein, which divides the large cell in fore wing $(\mathrm{M} 2+3)$.

Taphonomy. Male and female of Forcepsites michalskii are fossilized nearby and with the posterior part of the abdomen directed to each other. The two inclusions are in a cylindrical piece of nonautoclaved Baltic amber with a diameter of $15 \mathrm{~mm}$ and a height of $11 \mathrm{~mm}$ which is divided at about half of its height by an uneven border between two layers of resin flow. This border shows a layer of pyrite as part of its plane. One resin flow contains the two moths exposing their respective dorsal sides to this border. Long scales deriving from the rim of the female wing are preserved. The female imago has lost two legs, and its thorax is damaged. The other flow contains non-linear series of bubbles. Both individuals seem newly emerged as judged from the complete vesture of scales on the wings and the wings not being tattered. No scent organs could be identified on wings, abdomens, or legs. The only syninclusions preserved with the Microlepidoptera are trichomes, typical ones for Baltic amber. 
TABLE 1. Characters of female genitalia, male genitalia, and general characters. Non-genital characters with sexual dimorphism are shown in bold.

\begin{tabular}{|c|c|c|}
\hline Character & Female & Male \\
\hline Length (head to abdomen tip) & $\begin{array}{l}2850 \mu \mathrm{m} \\
\text { longer than male }\end{array}$ & $2625 \mu \mathrm{m}$ \\
\hline \multicolumn{3}{|l|}{ Head } \\
\hline Antenna & $\begin{array}{l}\text { filiform } \\
\text { upwards directed cilia organized in tiny } \\
\text { whorls } \\
1.6 \mathrm{~mm}, 1 / 2 \text { of wing length } \\
\text { ca. } 30 \text { flagellomers (left) } \\
\text { ca. } 30 \mu \mathrm{m} \\
\text { thinner than in male } \\
\text { scape and pedicel hardly thicker than } \\
\text { flagellomers }\end{array}$ & $\begin{array}{l}\text { filiform } \\
\text { upwards directed cilia organized in tiny } \\
\text { whorls } \\
2.3 \mathrm{~mm}, 2 / 3 \text { of wing length } \\
\mathbf{3 4} \text { flagellomers (left) } \\
\text { ca. } 50 \mu \mathrm{m} \\
\text { scape and pedicel hardly thicker than } \\
\text { flagellomers }\end{array}$ \\
\hline Eyes & $\begin{array}{l}\text { globular, diameter } 195 \mu \mathrm{m} \\
\text { ca. } 18 \text { ommatidia across the eye } \\
\text { hairs around dorsal side of eyes }\end{array}$ & $\begin{array}{l}\text { globular, diameter } 295 \mu \mathrm{m} \\
\text { larger than in female } \\
\text { ca. } 18 \text { ommatidia across the eye } \\
\text { hairs around dorsal side of eyes }\end{array}$ \\
\hline Proboscis & short (ca. $30 \mu \mathrm{m})$, thin, ribbed & $\begin{array}{l}\text { short (ca. } 30 \mu \mathrm{m} \text { ), thin, ribbed } \\
\text { galeae separated }\end{array}$ \\
\hline Maxillary palps & 5 segments, long, bent & $\begin{array}{l}5 \text { segments, long, bent } \\
\text { twice as thick as in female } \\
\text { ribbed }\end{array}$ \\
\hline Labial palps & with lateral bristles & with lateral bristles \\
\hline Vertex & with erected hair-like scales & with erected hair-like scales \\
\hline \multicolumn{3}{|l|}{ Abdomen } \\
\hline Width & $\begin{array}{l}655 \mu \mathrm{m} \text { maximum width } \\
\text { (abdominal segment } 3 \text { ) } \\
\text { wider than male, } \\
\text { in A2-4 }\end{array}$ & $\begin{array}{l}590 \mu \mathrm{m} \text { maximum width } \\
\text { (abdominal segment } 3 \text { ) }\end{array}$ \\
\hline \multicolumn{3}{|l|}{ Wings } \\
\hline Length & $3605 \mu \mathrm{m}$ & $3280 \mu \mathrm{m}$ \\
\hline Wing / body length & $1.26 \mathrm{~mm}$ & $1.25 \mathrm{~mm}$ \\
\hline Shape & lanceolate with acute wing tip & lanceolate with acute wing tip \\
\hline Frenulum / retinaculum & $492 \mu \mathrm{m}$, retinaculum not visible & both not visible \\
\hline Venation & $\begin{array}{l}\text { front wing: } \\
S, R 1-5, M 1-3, C u 1, C u 2,1 A+2 A \\
\text { all veins separate, } \\
\text { large cell, subdivided } \\
\text { by two weak M veins within } \\
\text { hind wing: } \\
\text { visible only partly, } \\
\text { heteroneurous }\end{array}$ & $\begin{array}{l}\text { seemingly both the same, } \\
\text { but mostly hidden behind } \\
\text { hind wing, } \\
\text { and behind abdomen, respectively }\end{array}$ \\
\hline Scales & $\begin{array}{l}\text { wings tightly covered with scales } \\
\text { no cilia, but long scales at the } \\
\text { rim of the wings }\end{array}$ & $\begin{array}{l}\text { wings tightly covered with scales } \\
\text { no cilia, but long scales at the } \\
\text { rim of the wings }\end{array}$ \\
\hline
\end{tabular}

\section{DISCUSSION}

\section{Random Co-occurrence or a Preserved Mating?}

The enclosed moths are male and female representatives of the same species and are arranged nearby with the abdomens oriented to each other. Yet, the genitals of the moths are not in direct con- tact, but in a close position. The dorsal/ventral orientation of male and female differs slightly, which is caused by a slight rotation within the body axis (especially of the male). The orientation of the posterior part of the abdomen of both moths is towards each other.

There are several cases known, where the situation of enclosure in the still liquid resin can 
TABLE 1 (continued).

\begin{tabular}{|c|c|c|}
\hline \multicolumn{3}{|l|}{ Abdomen } \\
\hline Scales & $\begin{array}{l}\text { scales dorsal, lateral, and at rims of } \\
\text { A3-5 } \\
\text { tiny hairs ventral }\end{array}$ & $\begin{array}{l}\text { no scales } \\
\text { tiny hairs ventral }\end{array}$ \\
\hline \multicolumn{3}{|l|}{ Legs } \\
\hline Length & $\begin{array}{l}\text { hind legs not preserved } \\
\text { fore and middle legs similar to male ones }\end{array}$ & $\begin{array}{l}\text { hind legs about the size } \\
\text { of body with wings }\end{array}$ \\
\hline Hairs & $\begin{array}{l}\text { bundle of hairs near trochanter of fore } \\
\text { legs }\end{array}$ & $\begin{array}{l}\text { bundle of hairs near trochanter of fore } \\
\text { legs }\end{array}$ \\
\hline Epiphysis & present & present \\
\hline Spur formula & $0-2-?$ & $0-2-4$ \\
\hline Scales & some at the outer side of the tibiae & some at the outer side of the tibiae \\
\hline Tarsi & $\begin{array}{l}\text { five tarsomeres, each with } 2-3 \text { small } \\
\text { spines distally } \\
\text { pretarsi with a pair of minuscule claws }\end{array}$ & $\begin{array}{l}\text { five tarsomeres, each with } 2-3 \text { small } \\
\text { spines distally } \\
\text { pretarsi with a pair of minuscule claws }\end{array}$ \\
\hline \multicolumn{3}{|l|}{ Genitalias } \\
\hline & $\begin{array}{l}\text { conical papillae anales with fine hairs, } \\
\text { outermost } 130 \mu \mathrm{m} \\
\text { of it exposed }\end{array}$ & $\begin{array}{l}\text { large clasping apparatus } \\
\text { (not the valvae) } \\
\text { built from sternit and tergit of A5, tergit } \\
\text { being longer, } \\
\text { both ending in each two lateral thorns } \\
\text { such forming a hole for the female } \\
\text { abdomen; } \\
\text { inside valvae (?) partly visible }\end{array}$ \\
\hline
\end{tabular}

induce a stress response, such as oviposition (Weitschat, 2009). The induction of mating behavior by the resin flow is generally not plausible, but the situation of enclosure demonstrates that slight movements within the fresh resin were possible.

There is also the question if this finding could also represent a random co-occurrence. The likelihood for such a random co-occurrence can be roughly estimated. Among insect inclusions moths occur with a frequency of about one in 250 inclusions in Baltic amber (Krzeminskaet al., 1991 (0.6\%); Hoffeins and Hoffeins, 2003 (0.4\%); Sontag, $2003(0.27 \%)$, and own observation). Given an individual amber with a moth inclusion, the chance for random co-occurrence of another moth is simply 1:250 (moths do not occur in swarms). The cooccurrence of the same taxon, or an abundant one which could be mistaken, is estimated to be $1: 10$ at best (Skalski, 1977), and another about 1:2 for having different sexes. Considering the further chances for close arrangement, both alignment of body axes, and a suitable body orientation, a likelihood for a random co-occurrence which could be misinterpreted as a mating event is far lower than the observed frequency as one out of 920 lepi- dopteran inclusions in the studied author's collection.

In conclusion, the most likely interpretation for this finding is that the moths were in copula, and the genitalia had been in contact but the individuals were slightly distracted from each other due to the resin flow (see discussion below).

\section{Taphonomy}

The relevance of careful analysis of resin flows for taphonomy of amber inclusions has been demonstrated by Coty et al. (2014) with their study of an ant - termite interaction preserved in Mexican Chiapas amber.

The occurrence of an in copula event is strongly supported by finding long scales derived from the rim of the female wing, which drifted for some distance into the direction of the male. This could indicate a strong laminar resin flow at this site which moved along their common axis, and could have drawn them apart for the short distance observed now. During mating of moths, the male may lose contact with the mating site and may be only fixed to the female by the clasping organ, with only the female making a contact to the surface. Such behavior and drag from sudden resin flow 
could be the reason why the female has lost both its hind legs. At the dorsal side of the moths, which had been exposed at the convex surface of this first laminar resin flow, the wing of the female and its underlying thorax is partly damaged (Figure 1.5). Putatively, these destructed areas represent feeding traces caused by other insects, most likely ants as often observed in amber specimens. Hence, after the first resin flow as embedding event, the dorsal sides will have been exposed for some time, long enough to allow predators to walk on this solid surface. The second resin flow, which covered this side later, could have been a fast and turbulent flow of resin, as indicated by a series of small bubbles arrayed in irregular curves found within it. This would be a typical taphonomic process for a so-called "Schlaube" of Baltic amber (Gröhn, 2016).

\section{Sexual Dimorphism}

Sexual dimorphism is difficult to observe in fossil species, from which only a few specimens are usually known. Characters not influenced by sex have to be diagnostic to allow secure species determination as a basis for the further differentiation between the sexes and elucidation of sexual dimorphism. Considering highly sexually dimorphic extant species, e.g., with brachypterous females like in many Psychidae (Scoble, 1995), an inference of both sexes belonging to one species would hardly be possible. Hence, only cases of weak sexual dimorphism can be reliably recognized in fossil species by statistic means and without finding them in copula. This underlines the importance of identified mating behavior in fossil species for description of such cases of strong sexual dimorphism. Such preserved findings of fossil mating may also approve correlation of previously known sexually dimorphic forms to belong to one species, even without the possibility of much statistical support. There is some chance that a preserved mating event could represent an interspecific or intergeneric mating as these are known from moths and butterflies (Ganyard and Brady, 1972; Deering and Scriber, 2002). However, these phenomena are much less abundant than intraspecific mating and hardly likely to be found as a rare fossil inclusion.

A non-allometric sexual dimorphism observed from Forcepsites michalskii is the separated galeae in the proboscisin the male. This may hint to a non-functional state, with male imagos of this species being non-feeding, as seen in many extant (male) Psychidae with vestigial or absent proboscis
(Scoble, 1995). Allometric sexual dimorphisms found here are: (1) The female is larger than the male, both in body size and wing length. However, the respective relations are almost the same. (2) In the female the abdomen is relatively and absolutely broader in comparison to the male. (3) The antennae of the male are much larger and thicker than in the female imago. In several extant species antennae are sexually dimorphic (Scoble, 1995), the well-developed male antennae serve for chemosensation of female pheromones. (4) The maxillary palps of the male are twice as thick as in the female and have a ribbed structure. (5) The eyes of the male are also larger but the number of ommatidia is about the same. Larger eyes will only receive more light and could be more sensitive; however, the resolution would be the same.

Long-range recognition of calling female moths takes place via male chemoreceptors whereas short-range recognition instead relies on visual identification (Groot, 2014). In Forcepsites michalskii, it also seems the female was the calling sex -as suggested by the larger antennal apparatus and eyes of the male.

\section{Habitat}

Based on the discussion presented above it is clear that individuals caught in copula can occur only in the place where this species lived and mated. Single individuals may be drifted by wind or visit non-habitat sites, like aquatic insects rarely found in Baltic amber (Wichardet al., 2009); for mating individuals instead, this could hardly be the case without getting separated. There seems to be no evidence in literature for mating of moths in flight. In contrast, in most Lepidoptera and in predominately nocturnal microlepidoptera (moths), females are "calling" the males by pheromones, thus determining the mating places (Groot, 2014). They may be flying before mating but in most cases they seem to be sessile and fanning for pheromone distribution. However, the sexes that call or search can also be reverse in some taxa, but for Tineidae the female is reported to be the calling sex (Wagner and Rosovsky, 1991; Scoble, 1995). In any case, the site of resin flow, i.e., the biotope with the amber producing trees, most likely was also the habitat of the clothes moth described herein.

\section{CONCLUSION}

A tineoid moth with a remarkable male genital apparatus is described as the new species and genus Forcepsites michalskii from Eocene Baltic 
amber. Female and male are preserved together in close position and with the abdomen oriented to each other, suggesting that these moths were trapped in the fresh resin during mating. A strong laminar resin flow, which is indicated by several drifted parts of the female's body, could have drawn them apart for the short distance observed now. This specimen could, therefore represent the first example of fossil Lepidoptera captured in copula.

It is assumed that Forcepsites michalskii was a forest-dwelling species, as individuals caught in copula can be documented only from the place where this species lived and mated.

Female and male of $F$. michalskii show sexual dimorphisms in body size, wing length, proportion of the abdomen, the size of the compound eyes, and the morphology of maxillary palps, as well of the antennae. Based on the distinct larger and thicker antennae of the male as well as on its larger eyes, it is suggested that the female could be the calling sex in this species, as also reported for extant Tineidae species.

\section{ACKNOWLEDGMENTS}

A. Michalski (Wroclaw, Poland) is acknowledged for providing this exceptional specimen and leading our attention to it. M. Schwarz from the Oberösterreichisches Landesmuseum (Linz, Austria) kindly supported the screening of their Lepidoptera collection. MKH was kindly funded by a scholarship of the Studienstiftung des deutschen Volkes and thanks S. Harzsch (Greifswald, Germany) for his support. We acknowledge the valuable scientific comments by M. Heikkilä and C. Haug (Munich, Germany) made on the manuscript, as well as comments by J. Krieger (Greifswald, Germany) and the support by C. MacGraphery (Freising, Germany) and Y. Goldman (Collinsville, $\mathrm{CT}, \mathrm{US}$ ) to check the English text as native speakers. Furthermore, we thank two anonymous reviewers for their helpful comments.

\section{REFERENCES}

Arillo, A. 2007. Paleoethology: fossilized behaviours in amber. Geologica Acta, 5(2):159-166. https://doi.org/10.1344/105.000000301

Börner, C. 1925. Lepidoptera, Schmetterlinge, p. 358-387. In Brohmer, P. (ed.). Fauna von Deutschland. Ein Bestimmungsbuch unserer heimischen Tierwelt. Quelle und Meyer, Leipzig.

Borkent, A. 1995. Biting Midges in the Cretaceous Amber of North America (Diptera: Ceratopogonidae). Backhuys Publishers, Leiden, The Netherlands.

Boucot, A.J. and Poinar Jr, G.O. 2010. Fossil Behavior Compendium. CRC Press, Boca Raton, p. 147-151.

Coty, D., Aria, C., Garrouste, R., Wils, P., Legendre, F. and Nel, A. 2014. The first ant-termite syninclusion in amber with CT-scan analysis of taphonomy. PLOS one, 9(8):e104410. https:/ /doi.org/10.1371/journal.pone.0104410

Deering, M.D. and Scriber, J.M. 2002. Field bioassays show heterospecific mating preference asymmetry between hybridizing North American Papilio butterfly species (Lepidoptera: Papilionidae). Journal of Ethology 20:25-33. https://doi.org/10.1007/s10164-002-0050-2

Fletcher, T.B. 1940. New generic names for microlepidoptera. Entomologist's Record, 52:17-19.

Ganyard, M.C. and Brady, Jr.U.E. 1972. Interspecific attraction in Lepidoptera in the field. Annals of the Entomological Society of America, 65 (6): 1279-1282. https://doi.org/10.1093/aesa/ 65.6 .1279

Gröhn, C. 2016. Einschlüsse im Baltischen Bernstein. Wachholtz Verlag - Murmann Publishers, Kiel, Hamburg.

Groot, A.T. 2014. Circadian rhythms of sexual activities in moths: A review. Frontiers in Ecology and Evolution 2:43. https://doi.org/10.3389/fevo.2014.00043

Hoffeins, C. and Hoffeins, H.W. 2003. Untersuchungen über die Häufigkeit von Inklusen in Baltischem und Bitterfelder Bernstein (Tertiär, Eozän) aus unselektierten Aufsammlungen unter besonderer Berücksichtigung der Ordnung Diptera. Studia Dipterologica, 10(2):381392.

Kozlov, M.V. 1987. New moth-like Lepidoptera from the Baltic amber. Paleontological Journal, 4:59-67. 
Kozlov, M.V. 1988. Paleontology of lepidopterans and problems of the phylogeny of the order Papilionida, p. 16-69. In Ponomarenko A.G. (ed.), The Mesozoic-Cenozoic Crisis in the Evolution of Insects. Academy of Sciences, Moscow.

Krzeminska, E., Krzeminski, W., Haenni, J.-P., and Dufour, C. 1991. Les Fantomes De L'Ambre. Muséed'histoire naturelle de Neuchâtel, Neuchâtel, Suisse.

Kusnezov, N. 1941. A Revision of Amber Lepidoptera. Paleontological Institute, USSR Academy of Sciences, Moscow \& Leningrad.

Latreille, P.A. 1810. Considérationsgénérales sur l'ordre naturel des animauxcomposant les classes des crustacés, des arachnides, et des insectes : avec un tableau méthodique de leurs genres, disposésenfamilles. Paris, Schoell.

Menken, S.B.J., Boomsma, J.J. and van Nieukerken, E.J. 2009. Large-scale evolutionary patterns of host plant associations in the Lepidoptera. Evolution, 64(4):1098-1119. https:// doi.org/10.1111/j.1558-5646.2009.00889.x

Rebel, H. 1934. Bernstein-Lepidopteren (aus der Sammlung Bachofen-Echt). Palaeobiologica, 6:1-16.

Rebel, H. 1935. Bernstein-Lepidopteren. Entomologische Zeitschrift Iris, 49:162-186.

Regier, J.C., Mitter, C., Davis, D.R., Harrison, T.L., Sohn J.-C., Cummings, M.P., Zwick, A., and Mitter, K.T. 2014. A molecular phylogeny and revised classification for the oldest ditrysian moth lineages (Lepidoptera: Tineoidea), with implications for ancestral feeding habits of the mega-diverse Ditrysia. Systematic Entomology, 40(2). https://doi.org/10.1111/syen.12110

Scoble, M.J. 1995. The Lepidoptera - Form, Function and Diversity. The Natural History Museum / Oxford University Press, Oxford.

Skalski, A.W. 1973. Studies on the Lepidoptera from fossil resins. Part II. Epiborkhausenites obscurotrimaculatus gen. et sp. nov. (Oecophoridae) and a Tineid-moth discovered in Baltic amber. Acta Palaeontologica Polonica, 18(1):153-160.

Skalski, A.W. 1974. Zwei neue Gattungen und Arten der Familie Tineidae aus dem Baltischen Bernstein. Studien an Lepidopteren aus fossilen Harzen V. Beiträge zur Entomologie, 1/ 4(24):97-104.

Skalski, A.W. 1977. Studies on the Lepidoptera from fossil resins. Part I. General remarks and descriptions of new genera and species of the families Tineidae and Oecophoridae from Baltic amber. Prace Museum Ziemi, 26:3-24.

Sohn, J.-C., Labandeira, C., Davis, D., and Mitter, C. 2012. An annotated catalog of fossil and subfossil Lepidoptera (Insecta: Holometabola) of the world. Zootaxa, 3286:1-132.

Sohn, J.-C. and Lamas, G. 2013. Corrections, additions, and nomenclatural notes to the recently published world catalog of fossil and subfossil Lepidoptera. Zootaxa, 3599:395-399.

Sontag, E. 2003. Animal inclusions in a sample of unselected Baltic amber. Acta Zoologica Cracoviensia, 46 (suppl.-Fossil Insects):431-440.

van Nieukerken, E.J., Kaila, L., Kitching, I.J., Kristensen, N.P., Lees, D.C., Minet, J., Mitter, C., Mutanen, M., Regier, J.C., Simonsen, T.J., Wahlberg, N., Yen, S.-H., Zahiri, R., Adamski, D., Baixeras, J., Bartsch, D., Bengtsson, B.Å., Brown, J.W., Bucheli, S.R., Davis, D.R., De Prins, J., De Prins, W., Epstein, M.E., Gentili-Poole, P., Gielis, C., Hätteschwiler, P., Hausmann, A., Holloway, J.D., Kallies, A., Karsholt, O., Kawahara, A.Y., Koster, S.J.C., Kozlov, M.V., Lafontaine, J.D., Lamas, G., Landry, J.-F., Lee, S., Nuss, M., Park, K.-T., Penz, C., Rota, J., Schintlmeister, A., Schmidt, B.C., Sohn, J.-C, Solis, M.A., Tarmann, G.M., Warren, A.D., Weller, S., Yakovlev, R.V., Zolotuhin, V.V., and Zwick, A. 2011. Order Lepidoptera Linnaeus, 1758. In Zhang, Z.-Q. (ed.), Animal biodiversity: An outline of higher-level classification and survey of taxonomic richness. Zootaxa, 3148:212-221.

von Linné, C. 1758. translated by William Turton (1806). Volume 1. A General System of Nature: Through the Three Grand Kingdoms of Animals, Vegetables, and Minerals, Systematically Divided into their Several Classes, Orders, Genera, Species, and Varieties. Lackington, Allen, and Co, London.

Wagner, D.L. and Rosovsky, J. 1991. Mating systems in primitive Lepidoptera, with emphasis on the reproductive behavior of Korscheltellus gracilis (Hepialidae). Zoological Journal of the Linnean Society, 102:277-303. https://doi.org/10.1111/j.1096-3642.1991.tb00003.x.

Weitschat, W. and Wichard, W. 2002. Atlas of Plants and Animals in Baltic amber. Verlag Friedrich Pfeil, München.

Weitschat, W. 2009. Jäger, Gejagte, Parasiten und blinde Passagiere - Momentaufnahmen aus dem Bernsteinwald. Denisia, 26(86):243-256. 
FISCHER \& HÖRNIG: MATING MOTHS

Wichard, W., Gröhn, C., and Seredszus, F. 2009. Aquatic Insects in Baltic Amber. Verlag Kessel, Remagen-Oberwinter. 